\title{
KEANEKARAGAMAN BUDAYA SEBAGAI JATI DIRI KOMUNITAS TUALANG SIAK TERHADAP PERTUNJUKAN MUSIK KOMPANG
}

\author{
Nursyirwan $^{1 *}$, Delfi Enida ${ }^{2 *}$, Alfalah ${ }^{3 *}$ \\ Program Studi Seni Musik Fakultas Seni Pertunjukan \\ Institut Seni Indonesia Padangpanjang \\ Jl. Bahder Johan, Guguak Malintang, Padangpanjang, Kota Padangpanjang, Kode Pos 27126 \\ Sumatera Barat. Indonesia \\ Email: doctornursyirwanmsn.ugm2011@gmail.com,delfienida@ymail.com, \\ asfalahpadangpanjang@gmail.com
}

\begin{abstract}
Abstrak
Penelitian keanekaragaman budaya sebagai jati diri orang-orang Tualang dalam memainkan musik kompang, adalah pengembangan penelitian musik kompang sebelumnya. Dalam menemukan jati diri masyarakat Tualang harus memulai hal-hal untuk diri sendiri, tentu tidak mudah dalam penemuan jati diri itu, sebagai penciri khas daerah yang heterogen. Tujuan tetap mempertahankan keberadaan musik kompang bagi masyarakat Tualang sebagai pengikat solidaritas kedaerahan komunitas. Data dikumpulkan melalui observasi, penelitian lapangan, wawancara, dan dokumentasi. Dianalisis dengan teknik deskriptif kualitatif, analisis interpretatif. Wawancara dilakukan dengan cara purposive sampling. Hasil penelitian: konteks musik Kompang dalam masyarakat Tualang, yakni pada perayaan pernikahan, khitanan, aqikahan, penyambutan tamu penting, acara festival, perayaan agama. Eksistensinya terlihat pada perkembangan wilayah musik kompang di daerah Tualang. Konsep musik kompang tidak terlepas dari latar belakang filosofi bermacam budaya, agama, dan kreativitas masyarakat atas perkembangan selera pasar. Kreativitas tidak hanya pada pelahiran musik sebagai ekspresi akan tetapi merupakan hasil dari adanya interaksi pemain di dalamnya yang melahirkan variasi kreativitas dalam sebuah pertunjukan.
\end{abstract}

Kata Kunci: musik, kompang, jati diri, multiculture.

\begin{abstract}
Research on cultural diversity as the identity of Tualang people in playing kompang music, is the development of previous kompang music research. In finding the identity of tualang people must start things for themselves, certainly not easy in the discovery of that identity, as a characteristic of heterogeneous areas. The purpose of maintaining the existence of kompang music for the Tualang community as a binding solidarity of the community area. Data is collected through observation, field research, interviews, and documentation. Analyzed with qualitative descriptive techniques, interpretative analysis. Interviews were conducted by purposive sampling. The result of the study: the context of kompang music in Tualang community, namely at wedding celebrations, aqiqah, welcoming party for important guest, festival events and religious celebrations. Its exixtence is seen inthe development of kompang music area in Tualang area. The concept of kompang music is inseperable from the philosopihical background of various cultures, religions, and creativity of the community over the development of market taste. Creativity is not only the birth of music as an expression but is the result of the interaction of the players in it which gives bitrh to a variety of creativity in performance.
\end{abstract}

Keywords: music, kompang, identity, multiculture.

\section{PENDAHULUAN}

Musik kompang merupakan produk masa lalu, dan telah menjadi salah satu genre seni musik yang berkembang sampai saat ini sebagai salah satu bagian dari tradisi seni pertunjukan bersifat kontekstual, seremoni dalam kehidupan pendukungnya sehari-hari. Berdasarkan penelitian yang dilaksanakan di daerah Tualang-Siak, keberadaan musik kompang yang mereka miliki dapat dikategorikan kepada hal-hal bersifat unik, menarik, ensensial yang menjadi kajian meliputi karakter, sifat, watak, dan kepribadian dari seniman pendukungnya.

Musik Kompang adalah permainan alat musik yang diiringi dengan nyanyian dan syair lagu-lagu bernafaskan Islam. Permainan musik Kompang memiliki perbedaan pada motif ritme lagu, baik variasi pukulan dan teknik permainan. Musik Kompang memiliki 12 (dua belas) jenis pukulan, yakni: mabon, ngendong, pecah limo, nyarang, nginan, tratat, pecah 


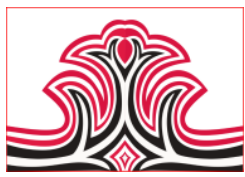

rapat, nginan nyarang, mecah nginan, selang ngendong, selang pecah rapat, dan jidor (Armes, 2015: 41).

Musik Kompang bersumber pada kitab Al-Barzanji. Barzanji merupakan kitab yang berisikan doa-doa atau puji-pujian terhadap Nabi Muhammad SAW. Pujipujian itu mengisahkan sifat-sifat mulia yang dimiliki Nabi Muhammad SAW, serta berbagai peristiwa untuk dijadikan teladan bagi umat manusia (Nursyirwan, 2000: 3). Musik Kompang sebagai seni pertunjukan atau seni 'bunyi-bunyian', sejalan dengan yang dimaksudkan Sumandiyo Hadi yang mengatakan, seni tidak lepas dari ada penonton, pendengar, pengamat (audience) yang membicarakan apresiasi, tanggapan atau respon (Hadi, 2012: 1). Konteks pertunjukan musik Kompang di Tualang dapat dilihat yakni pada acara; resepsi pernikahan, khitanan, aqikahan, festival, perayaan hari besar keagamaan (Islam) dan penyambutan tamu penting, seperti para pejabat yang berkunjung ke daerah.

Masyarakat Tualang terdiri atas berbagai budaya, seperti budaya: Melayu, Bugis, Banjar, Minangkabau, Jawa, Batak, dan lain-lain. Mereka mempunyai perbedaan dari segi adat, tradisi, bahasa, dan agama, namun mayoritasnya menjadi pendukung budaya Melayu (Suwardi MS, 2008: 109).

Keberagaman budaya yang ada di daerah Tualang, Siak Riau, telah mampu menciptakan sistem interaksi permainan musik Kompang yang saling berkulindan, dan tercermin dalam pola pukulan yang memiliki tatanan varian pola pukulan. Pola pukulan demikian berpengaruh terhadap gejala entitas bunyi terutama bunyi pada pola-pola pukulan berjalin ('interlocking'). Berkaitan dengan gejala yang demikian, Dede Pramoyoza dalam pengantar buku Pergelaran sebuah Mozaik Penelitian Seni-Budaya, mengatakan, belakangan ilmu-ilmu seni pementasan ditantang oleh kehadiran performance studies, hal demikian dikarenakan peneliti saat ini dalam kekinian harus mampu mengurai gejala-gejala kesenian yang ada di sekeliling mereka dengan piranti yang mutakhir, salah satunya 'kacamata' performance studies (Simatupang, 2013: v)

\section{KAJIAN TEORI}

Berbagai gejala atau permasalahan yang muncul dalam keberadaan musik kompang, maka budaya yang telah terpatri oleh masa pendukungnya tidak dapat dilepaskan dari kebudayaan yang menghasilkannya dengan berbagai kreativitas yang dilakukan. Ruang lingkup sosial budaya dan tipe-tipe masyarakat juga
Gorga : Jurnal Seni Rupa

Volume 10 Nomor 01 Januari-Juni 2021

p-ISSN: 2301-5942 | e-ISSN: 2580-2380

tidak terlepas dari usaha menumbuhkan ciri atau gaya tertentu terhadap seni kompang. Kreativitas sebagaimana dinyatakan Alfred North Whitehead, bukan berarti aktivitas yang dinilai positif, dengan maksud untuk menyatakan kemunculan ide baru. Kemunculan ide baru secara terus-menerus tergantung pada sifat realitas, sehingga dengan demikian kreativitas adalah "prinsip tertinggi" sesuai dengan masuknya beberapa bagian ke dalam suatu kesatuan yang rumit. Whitehead menempatkan alam semesta pada posisi yang "kreatif berkembang menjadi sesuatu yang baru" (Whitehead, 1929: 25-26, 260).

Teori Whitehead, dapat pula dikuatkan dengan teori McHale yang mengatakan, tingkat kemungkinan pilihan sekarang dan kemungkinan hasilnya di masa depan harus diketahui jika peneliti menciptakan masa depan. Peneliti harus menciptakan kemajuan teknologi yang cukup untuk membuat pilihan masa depan yang mungkin, dan kini peneliti perlu secara sadar mencurahkan segenap tenaga peneliti sendiri untuk menciptakan "bentuk-bentuk sosial", rencana institusional, dan juga ideologi yang memungkinkan peneliti memanfaatkan kemampuan peneliti semakin berkembang secara langsung dan tepat guna untuk melayani masa kini dan masa depan (McHale, 1969: $52)$.

Terkait dengan bentuk kreativitas yang dimaksud dalam topik pengembangan seni kompang di masa depan, tentu berbagai bentuk tantangan di masa depan secara serius harus mengakui bahwa ilmu sosiologi cenderung memberikan dukungan pada pelaku atau masyarakat sebagai penikmat, dapat memberikan ideide yang menyebabkan pelaku lebih menyesuaikan diri terhadap masa depan ketimbang menciptakan sesuatu yang baru. Secara teori perubahan sosial jelas lebih bermanfaat bagi pengamat/penikmat ketimbang bagi pencipta, artinya pelaku seni kompang lebih diharapkan membangun perubahan tetapi bukan teori untuk mengubah. Tentu saja rentetan pilihan tak terbatas, bahwa pelaku seni kompang sama sekali bebas menciptakan salah satu di antara sejumlah kemungkinan masa depan yang tak terbatas dalam bentuk pengembangan itu.

Penalaran peneliti yang demikian dapat diselaraskan dengan penguatan yang disampaikan Whitehead, karena penciptaan diri sendiri oleh organisme, penciptaan lingkungannya sendiri oleh organisme tak berlaku bagi organisme selaku kesatuan yang terisolasi, karena organisme tunggal hampir tanpa bantuan. Masyarakat dan organisme bekerjasama dan jika upaya bekerjasama ini cukup giat, maka lingkungan terlihat 
mempunyai "kelenturan" yang mengubah seluruh aspek estetika dari evolusi (Whitehead, 1929: 105).

Selanjutnya, teori perubahan yang peneliti pilih, untuk mengantisipiasi agar musik kompang selalu dijadikan sebagai 'jati diri' budaya pada 'komunitas Tualang'. Secara kontekstual penelitian ini memerlukan teori yang disampaikan oleh Arnold Hauser yang mengatakan, bahwa 'nyanyian rakyat' selalu berubahubah, nyanyian rakyat tidak memiliki bentuk yang permanen, setiap versinya selalu menampilkan tahaptahap peralihan, ("nyanyian rakyat, atau kesenian rakyat yang disampaikan Hauser, dalam konsep penelitian ini diartikan nyanyian tradisional atau kesenian tradisional'). Dalam tahap perkembangannya kesenian rakyat cenderung lebih sulit dibandingkan dengan seni yang lain (populer). Dan dalam sejarahnya cenderung ditampilkan untuk waktu yang lebih lama, namun dari kenyataannya kesenian rakyat sering ditampilkan dalam bentuk-bentuk yang insidental (Hauser, 1982: 575-576). Teori yang disampaikan Hauser, tentu saja bagi para peneliti lainnya boleh sejalan boleh tidak. Untuk permasalahan seni kompang pada penelitian ini teori Hauser sesuai dengan kondisi yang di alami dalam perkembangan seni rakyat di wilayah Tualang, Siak, Riau, dan daerah Melayu pada umumnya.

Berkaitan dengan musik kompang, teori yang demikian dapat dianalisiskan, bahwa beberapa faktor eksternal adalah sebagai penyebab perubahan di dalam sistem sosiokultural pertumbuhan dan perkembangan seni kompang, namun tekanan utamanya diletakkan pada kekurangan penyebab khusus; pada umumnya sistem sosiokultural berubah sesuai dengan hukum logikanya sendiri. Hal ini bisa saja lebih ditujukan kepada kemajuan dan perkembangan arus globalisasi, yang terkadang secara eksternal lebih mempengaruhi, terhadap perubahan yang terjadi. Secara kontekstual jelas teori perubahan sangat diperlukan untuk mengamati terhadap segala perubahan yang terjadi dalam keberadaan musik kompang saat ini, sebagai jati dirinya.

\section{METODE PENELITIAN}

Metode penelitian dirancang dalam bentuk penelitian kualitatif. Penelitian ini mengkaji musik dan budaya di Tualang melalui pengkajian etnografi, dan antropologi meliputi interpretasi atas identity, dan representasi budaya kesenian kompang di Tualang. Adapun pendekatan penelitian dilakukan secara "emik", di dalam artian peneliti menggunakan partisipant (informan setempat). Pendekatan penelitian seperti ini adalah yang ideal, sebab dapat menghilangkan batas sosial antara si peneliti dan si informan, sehingga pendekatan dapat dilakukan secara kekeluargaan. Tentu saja bandingan pendekatan yang harus diwaspadai adalah pendekatan secara "etik" maksudnya peneliti menggunakan sudut pandang observer (peneliti sendiri), dengan teknik mempersiapkan pertanyaan yang baik, bagus, sempurna, tanpa melihat psikologis informan, yang akhirnya berakibat, informan hanya memberikan jawaban pendek dengan kalimat ungkap: ya, tidak, tidak tahu (jawaban simpel/ pendek). Pendekakan penelitian secara "etik" dilakukan apabila informan tidak mengerti bahasa'nya' ('nya'=informan).

Jenis data yang digunakan dalam penelitan ini yaitu data kualitatif. Julia Brannen mengatakan; penelitian dengan cara kualitatif sesuai dengan pendefenisian konsep-konsep yang sangat umum dengan cara observasi partisipatoris (peneliti ikut terlibat dalam penelitian) (Brannen, 2005: 11). Jadi keterlibatan peneliti secara langsung dalam penelitian pendukung komunitas Tualang terhadap musik kompang adalah jembatan dalam mencapai penafsiran data-data yang didapat untuk mencapai kesimpulan dalam menjawab setiap permasalahan pada topik yang diajukan.

Dokumentasi yang peneliti lakukan berpedoman kepada teori yang disampaikan Bruno Nettl mengatakan, "daya ingat manusia tidak dapat mengingat persis apa yang terdengar baru sepuluh detik yang lalu, karena itu notasi sangat penting dalam penelitian kesenian" (Nettl, 1964: 98).

\section{HASIL DAN PEMBAHASAN}

\section{Hasil}

Kondisi keberagaman perlakuan terhadap musik kompang yang tersebar dalam commnunity Melayu Riau dapat dilihat sebagai keberagaman gaya/cara membangun potensi dalam membesarkan warisan masa lalu, sedangkan secara struktural dapat dikategorikan sebagai satu genre musik yang disebut kompang (musik). Dalam konteks tersebut beberapa genre musik yang menjadi kekayaan produk budaya terdapat dalam community Melayu di Riau. Di sisi yang lain, Sari, (2020: 452), menuliskan, bahwa memiliki peninggalan warisan budaya yang berbeda dan pola hidup dan tingkah laku yang beragam menjadikan struktur pola pikir masyarakat yang plural, baik mitos maupun sistem nilai dari setiap masyarakatnya dalam menghasilkan suatu unsur kebudayaan yang tidak sama. Sehingga dapat mempererat ikatan solidaritas, dan menjadi ciri dan pembeda dari masing-masing kelompok masyarakat. 
Interaksi musik Kompang adalah bagaimana upaya seniman perseorangan memproyeksikan kepada kelompok pemain Kompang lainnya. Bentuk pertunjukan Kompang dapat dibedakan menurut ruang (tempat) dan waktu dalam konteks peristiwa budaya masyarakatnya. Adapun beberapa bentuk pertunjukan Kompang di Tualang Siak-Riau antara lain; a. Kompang Arak-Arakan, b. Kompang Syukuran (Hajatan), dan c. Kompang Persembahan, Festival atau Lomba.

\section{Pembahasan}

\section{1). Keberagaman dan Komunitas sebagai Pemersatu}

Spesifikasi hanyalah gambaran bagaimana masyarakat mengembangkan kesukuannya dalam mempertahankan seni budaya milik daerah masyarakat Melayu Riau umumnya komunitas Tualang Siak pada khususnya. 'Kompang' adalah alat instrumen musik tergolong jenis alat pukul menyerupai alat instrumen musik 'rebana'. "Musik kompang" yaitu: musik yang diiringi nyanyian dengan teks lagu-lagu bernafaskan Islam (Nursyirwan, 2000: 3-4). Keberadaan musik kompang oleh masyarakat masih difungsikan untuk mengiringi beberapa acara, antara lain: (a) upacara tepuk tepung tawar; (b) upacara berinai curi (c) rarak pengantin, (d) turun mandi, (e) sunatan, (f) upacara khatam Quran, (g) pencak silat, (h) upacara penyambutan tamu resmi, dan (i) festival musik kompang.

Daerah Tualang-Siak dengan adanya PT Indah Kiat (Pabrik Kertas), dalam usaha mencari kerja jelas masyarakatnya terdiri dari berbagai suku dan budaya seperti: suku Melayu, Minang, Jawa, Batak, China, India, atau dapat digolongkan pada masyarakat yang terdiri dari berbagai budaya. Dalam bekerja mereka terkadang bisa saja terjadi perbedaan pendapat antar kepentingan, dalam hal ini disebut mempertahankan wilayah sebagai penunjukan jati diri. Kata jati diri dimaksud dalam penelitian ini, bagaimana upaya masyarakat/seniman pendukung yang terdiri dari berbagai suku dan adat istiadat, menampilkan musik kompang sebagai penciri khas milik kedaerahan komunitas Tualang. Sebuah komparatif ketika orang Indonesia, pergi ke Belanda, sebetulnya cukup sulit membuat penggolongan mereka yang beragam, namun mereka berlatar belakang yang sama, walau terdiri dari keluarga campuran dan pengalaman budaya yang dipandang elit ketika penjajahan di Hindia Belanda (Fridus Steijlen dalam Hatley, 2014: 247). Namun demikian inilah khasnya masyarakat Tualang, yang sudah tidak asing lagi dalam kehidupan beragamnya suku Melayu yang dominan, sehingga mereka berbaur dalam satu wadah yaitu kesenian musik kompang.
Gorga : Jurnal Seni Rupa

Volume 10 Nomor 01 Januari-Juni 2021

p-ISSN: 2301-5942 | e-ISSN: 2580-2380

Banyak kelompok yang mengadopsi istilah 'komunitas', yang menandakan sekelompok orang dengan sebuah perasaan kesamaan identitas, yang didasarkan atas hasrat dan komitmen kesenian mereka (Hatley, 2014: 33-34). Hal demikian dapat dihubungkan bahwa komunitas "Kompang Melayu" dalam penelitian ini, adalah kompang yang hidup dalam komunitas Melayu Riau umumnya, beragam keturunan community Melayu yang ada di 'nusantara' (Sumatera, Jawa, Kalimantan dan Sulawesi), namun memiliki hasrat yang sama dalam membangun tumbuh dan berkambangnya kesenian kompang. Berdasarkan hal itu, kiranya batasan penelitian dapat dipersempit, yaitu komunitas yang terdapat di kecamatan Tualang, Kabupaten Siak, Provinsi Riau.

Dalam memenuhi kebutuhan sehari-hari, sumber kehidupan masyarakat yang bermacam ragam menjadikan perekonomian di Kota Tualang-Siak agak seimbang. Setelah berakhirnya gaya kehidupan tradisi kemudian berganti dengan gaya kehidupan berteknologi, kelihatannya terjadi beberapa ketimpangan di daerah Tualang-Siak seperti, nasib seni musik yang masih hidup mulai tidak diperhatikan secara serius, sebab pendukungnya lebih terfokusnya pada usaha pemenuhan kebutuhan sehari-hari, sehingga nasib seni dan budaya tradisi yang ada, harus berjuang untuk bertahan hidup "melawan" kemajuan teknologi (Wawancara, 2018). Menyikapi berbagai gejala yang bakal muncul dalam keberadaan musik kompang itu, maka budaya yang telah terpatri oleh masa pendukungnya dalam usaha menumbuhkan ciri atau gaya tertentu terhadap musik kompang, hal demikian jelas bertujuan agar musik kompang dalam community Melayu selalu dapat dijadikan sebagai penciri budaya Melayu yang berlandaskan kepada Islam.

\section{2). Teknik dan Variasi Pukulan}

Musik Kompang dimainkan dengan teknik interloking. Teknik interloking yang dimainkan seperti: mabon, mecah, mecah gendong, apek mecah gendong, selang gendong, apek selang gendong, teratat satu, teratat delapan, teratat dua belas, teratat delapan belas, menginan, dan cedol (Nursyirwan, 2008: 3). Teknik interloking sebagai ekspresi dalam permainan Kompang secara berurutan terutama mabon sebagai dasar pemain yang memainkan pertama kali, kemudian diikuti oleh mecah dan dilanjutkan dengan penggabungan antara mabon dan mecah.

Motif-motif pukulan secara bersaut-sautan yang memancing ekspresi secara emosi musikal dan memberikan motivasi kepada pemain. Sewaktu mabon dan mecah bermain maka pemain yang ketiga mengikuti teknik pukulan mecah gendong. Demikian 
seterusnya terhadap motif pukulan apek mecah gendong, selang gendong, apek selang gendong, teratat satu, teratat delapan, teratat dua belas, teratat delapan belas, menginan, dan cedol. Untuk memunculkan ekspresi yang lebih maksimal dimunculkan motif pemecah untuk menjalin nada-nada yang dihasilkan oleh kedua belas orang pemain. Guna mengatur tempo motif diwakilkan oleh cedol (gendang bermuka satu). Motif pukulan yang dapat ditirukan dengan kata-kata "Pang-Pang-Pang-Pang-Pang-PangPang-Pang ... dan Pung-Pung-Pung-Pung-Pung-PungPung-Pung. Bunyi yang dihasilkan dari pukulan ini adalah "pak" dan "pung".

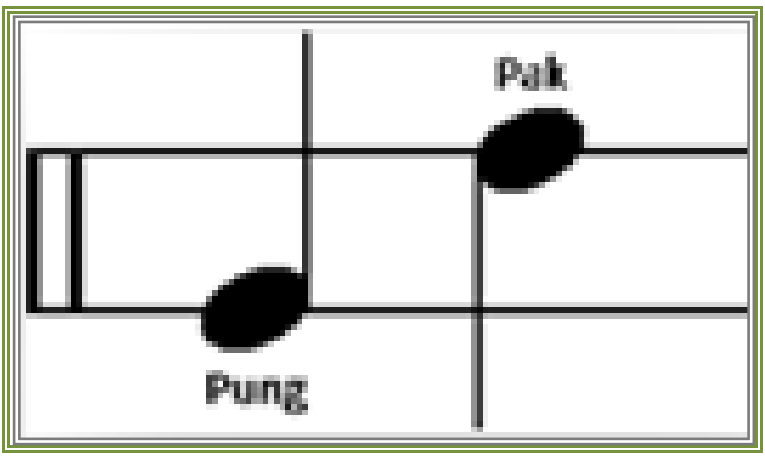

Gambar 1. Notasi 1.

Bunyi Pukulan Kompang (Nursyirwan, 2019)

Dalam pertunjukan musik Kompang, mabon dan mecah merupakan dua pukulan induk dari pukulanpukulan kompang yang lain. Pemain kompang mewakili pukulan kompang, seperti motif berikut.

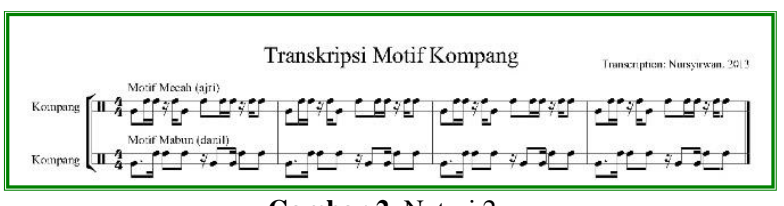

Gambar 2. Notasi 2.

Motif Pukulan 'Mecah' dan Motif Pukulan 'Mabun' Transkripsi (Nursyirwan, 2019)

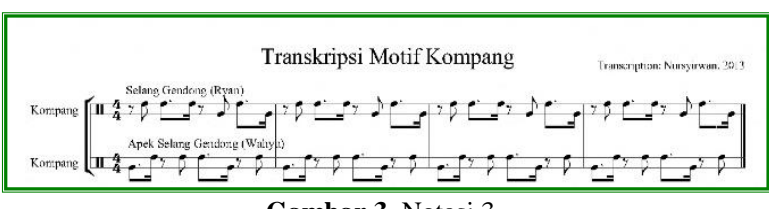

Gambar 3. Notasi 3.

Motif Pukulan 'Selang Gendong' dan Motif Pukulan 'Apek Selang Gendong'

Transkripsi (Nursyirwan, 2019)

Sistem permainan musik Kompang terdiri atas kesatuan permainan pola-pola gendang bermuka satu dan pelafalan vokal yang menyenandungkan teks-teks kitab barzanji. Keberadaan vokal sejalan dengan permainan pola-pola pukulan Kompang. Pengucapan huruf-huruf Hijaiyah sangat terikat dengan hukum-hukum bacaan yang lazim disebut Tartil atau ilmu Tajuwid. Berikut bentuk notasi 12 motif pukulan kompang di Tualang.

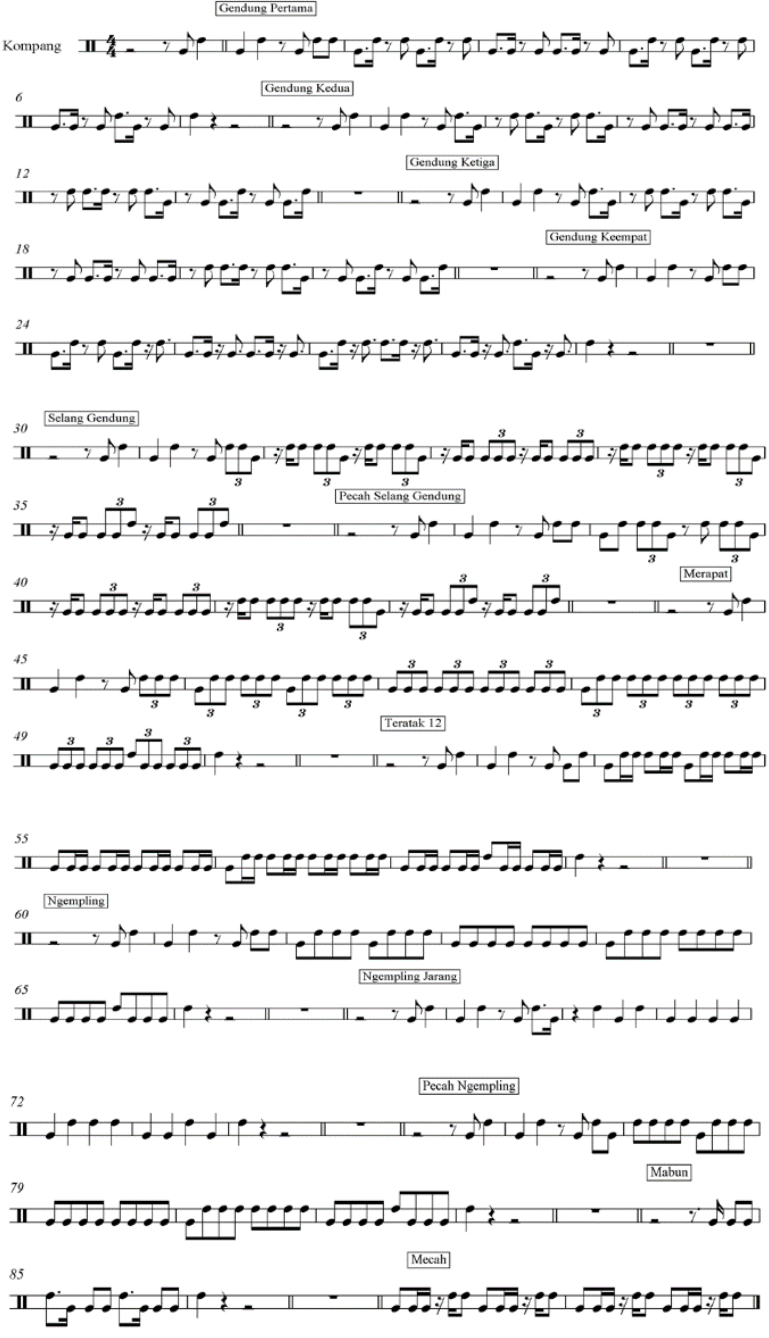

Gambar 4. Notasi 4.

Notasi Pukulan Kompang

(Enida, 2019)

Di dalam permainan musik Kompang, keberadaan 'Makhorijul_Huruf' tidak hanya dalam konteks pembacaan huruf Hijjaiyah, akan tetapi dipengaruhi tingkat pemaknaan para pemain terhadap makna teks lagu. Oleh sebab itu, 'Makhorijul_Huruf' dalam permainan musik Kompang sangat memberi arti terhadap keindahan permainan. Pada kenyataannya masyarakat Tualang, tidak seluruh kelompok musik Kompang masih mempertahankan 'Makhorijul_Huruf' sebagai bagian terpenting dalam permainan, yakni pada kelompok anak-anak, remaja laki-laki, dan remaja wanita. 082391536383.

\section{3). Sistem Pertunjukan}

Bentuk-bentuk penyajian pertunjukan Kompang dapat dibedakan menurut ruang (tempat) dan waktu (pelaksanaan) dalam konteks peristiwa budaya masyarakatnya. Adapun beberapa bentuk pertunjukan Kompang di Tualang, Siak-Riau adalah sebagai berikut: 


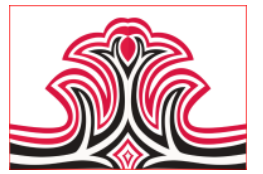

(1). Kompang Arak-Arakan

\section{a. Arak-Arakan Hari Besar Islam}

Kompang arak-arakan pada kegiatan memperingati peristiwa hari-hari besar umat Islam, seperti; Maulid Nabi Muhammad SAW, penyambutan bulan Ramadhan, hari raya Idul Fitri, perayaan Musabaqah Tillawatil Qur'an (MTQ).

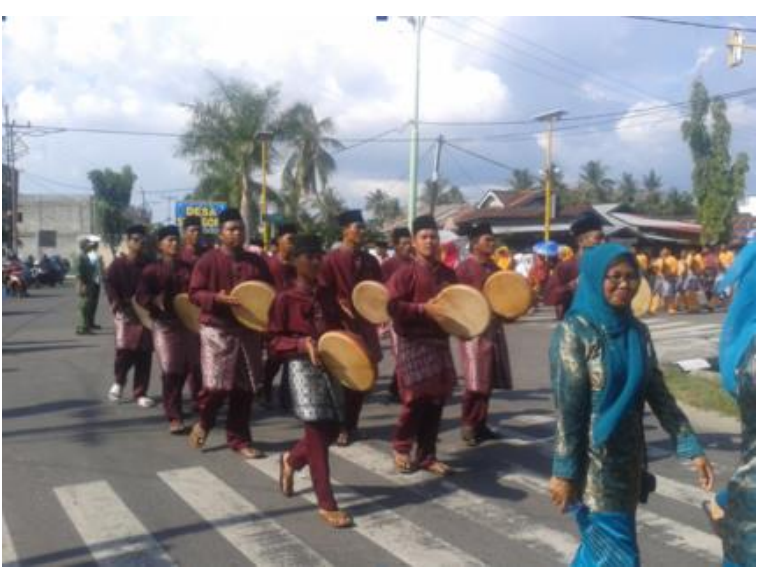

Gambar 5

Kompang Arak-arakan pada Pawai MTQ Tingkat Kabupaten di Kota Siak

(Nursyirwan, 2019)

\section{b. Arak-Arakan Pesta Perkawinan}

Kompang arak-arakan pada pesta perkawinan. Arakarakan bersama sajian Kompang ini menjadi bagian pada prosesi acara perkawinan. Pertunjukan Kompang ini hadir pada saat dilakukannya prosesi mengantar mempelai pria bersama-sama dengan keluarga ke rumah mempelai wanita.

Pertunjukan arak-arakan disajikan dengan melantunkan shalawat dan salam serta puji-pujian dengan syair teks yang meriwayatkan hadist. Syair teks riwayat hadist sebagai materi lantunan vokal, dilafaskan bersamasama oleh rombongan kelompok Kompang sembari diiringi oleh pola permainan motif-motif pukulan Kompang yang dibawakan dalam bentuk 'pengulangan' hingga 'variasi'.
Gorga : Jurnal Seni Rupa

Volume 10 Nomor 01 Januari-Juni 2021

p-ISSN: 2301-5942 | e-ISSN: 2580-2380

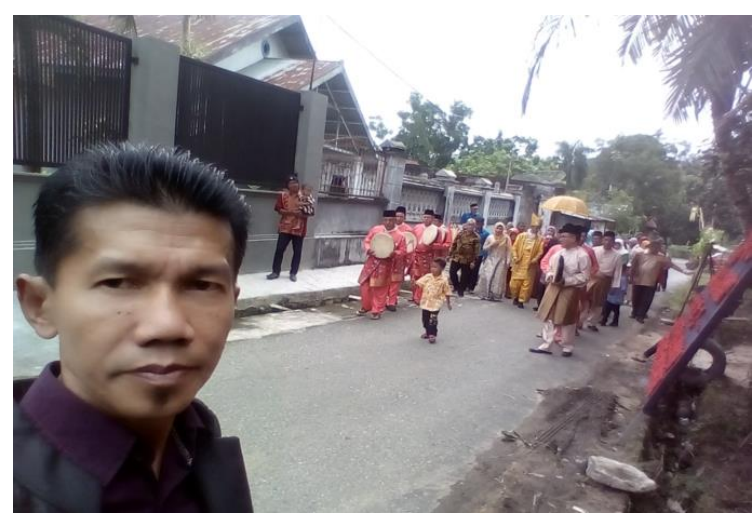

Gambar 6.

“Kompang Arak Pengantin” di Desa Maredan, Kecamatan Tualang (Nursyirwan, 2019)

\section{(2). Kompang Syukuran dan Hajatan}

\section{a. Musik Kompang Peringatan}

Pertunjukan musik Kompang memperingati hari lahir Rosullullah SAW/ Maulid Nabi. Pertunjukan Kompang dilakukan di dalam rumah, surau, atau Mesjid. Kompang disajikan bersama lantunan irama teks rawi dan kitab barzanji sebagai lafas dan ungkapan rasa syukur. Materi permainan disajikan dalam bentuk motif-motif pukulan Kompang bersama lantunan lafas irama teks Rawi dan kitab barzanji.

\section{b. Musik Kompang Hajatan}

Pertunjukan Kompang pada hajatan sebagai bentuk perwujudan rasa syukur dan telah menjalankan sunah Rasul, seperti tepuk tepung tawar, sunatan, dan akikah. Secara teknis pertunjukan Kompang dilakukan di rumah yang melaksanakan hajatan atau syukuran. Pertunjukan Kompang disajikan oleh kelompok Kompang dengan cara duduk, dan tergabung ke dalam keramaian penonton.

Pada prosesi tepuk tepung tawar, permainan motifmotif pukulan Kompang dimainkan secara berulangulang mengiringi doa restu serta kata-kata petuah dari pihak keluarga terhadap kedua mempelai hingga pembacaan dilakukan pembacaan do'a. Pelantunan shalawat dan salam serta puji-pujian dari syair teks yang berasal dari hadist yang diperoleh dari seorang pengajaran guru kompang kepada murid pemain kompang lainnya, kemudian diiringi oleh permainan motif-motif pukulan Kompang yang dibawakan secara berulang-ulang dengan variasi-variasi yang semakin menarik, dan terkadang dapat memotivasi penonton untuk dapat lebur dalam atraksi pukulan kompang yang dinamis. 


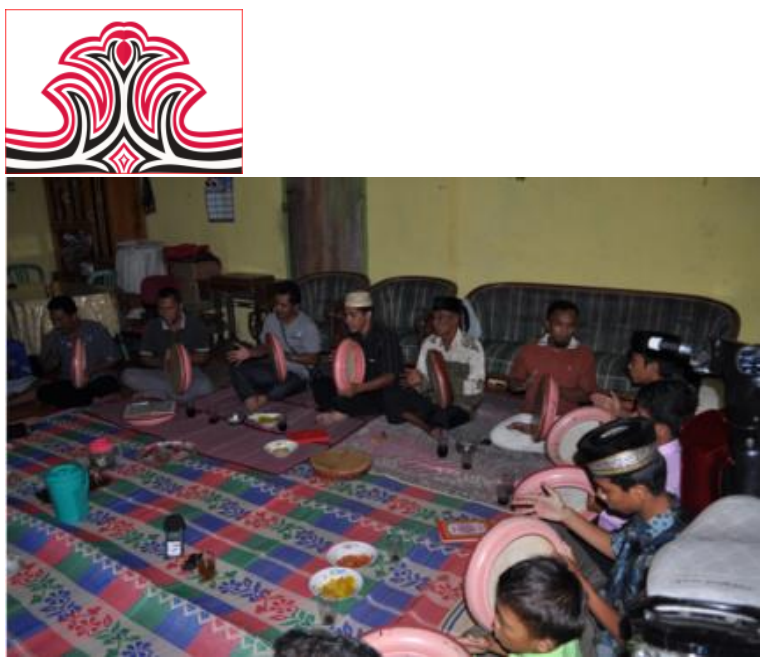

Gambar 7.

Pertunjukan Kompang Teknik Duduk Desa Pinang Sebatang Timur, Kecamatan Tualang

(Nursyirwan, 2019)

\section{(3). Kompang Persembahan, Festival atau Lomba}

Pertunjukan Kompang ini disajikan sebagai persembahan penyambutan tamu, pisah sambut jabatan, festival dan lomba. Pada persembahan festival atau lomba, Kompang dipentaskan di atas panggung, dipertontonkan kepada khalayak ramai dan dinilai oleh juri untuk mendapatkan kelompok-kelompok yang terbaik dalam penyajiannya. Klasifikasi penilaian Kompang Festival dan Lomba biasanya dilihat dari kerampakan permainan selama pertunjukan, penghayatan terhadap permainan Kompang, dan penilaian terhadap pola gerakan, atraksi maupun pencak silat.

Estetika pertunjukan menggunakan kostum sebagai penunjang kebutuhan dalam pertunjukan yang ideal dan seragam. Adapun kostum yang digunakan adalah busana Melayu, ideal dengan nilai-nilai budaya Melayu sebagaimana tampak pada gambar berikut ini.

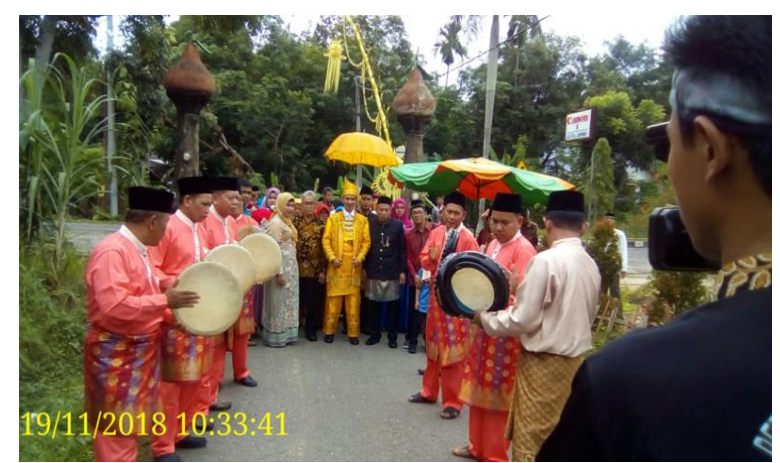

Gambar 8.

Busana Pemain Musik Kompang (Nursyirwan, 2019)

(4). Interaksi dalam Pertunjukan Musik Kompang Interaksi merupakan suatu proses hubungan timbal balik yang saling mempengaruhi. Dalam hubungan sosial, interaksi sosial dimaksud sebagai hubungan yang dinamis antara perseorangan dan perseorangan, antara perseorangan dengan kelompok dan antara
Gorga : Jurnal Seni Rupa

Volume 10 Nomor 01 Januari-Juni 2021

p-ISSN: 2301-5942 | e-ISSN: 2580-2380

kelompok dan kelompok (Depdiknas, 2008: 542). Adapun hubungan timbal balik dalam wujud yang saling mempengaruhi tersebut dipandang sebagai suatu proses permainan musik Kompang dalam hubungan sosial masyarakatnya. Pemain Kompang 'satu' atau yang memainkan 'pola ritme dasar' menjadi acuan pemain 'dua' dan 'tiga' untuk pengembangan yang disebut 'pecahan dan peningkah'.

Untuk mengintegrasikan diri dalam permainan dan komunitasnya pemain membentuk jaringan "multi arah". Individu ataupun kelompok-kelompok berkomunikasi dengan efektif dengan dasar latar belakang pengalaman, improvisasi, dan latar belakang budaya. Hal tersebut bertujuan untuk mengintegrasikan identitas grup yang tergantung pada tematik segmen (bagian) pertunjukan yang mereka anggap menarik dimunculkan interaksi. Interaksi semakin menarik dan meriah bila terjadi saling sahut-menyahut dalam permainan kompang yang diikuti dengan ekspresi gerakan dan vokal.

Eric Wolff menyatakan bahwa fungsi pertunjukan sebagai bagian dari hajat hidup masyarakat adalah digunakan sebagai bentuk penandaan dari suatu peristiwa atau suatu wahana untuk melakukan komunikasi yang bersifat sosial atau spiritual (Wolf, 1983: 170-171). Pertunjukan Kompang sebagai produk sosial masyarakat secara tidak lansung berinteraksi dengan peristiwa-peristiwa budaya masyarakat lainnya. Interaksi terjadi secara momentum pada peristiwaperistiwa budaya masyarakat bersama kehadiran pertunjukan Kompang, baik itu pada arak-arakan/ pawai, arak-arakan pengantin, pertunjukan di rumah pada prosesi tepung tawar, terutama dalam memperingati hari-hari besar umat Islam.

Pada wujud sosialnya adalah mengenai hubunganhubungan masyarakatnya. Pada wujud spritualnya ialah puji-pujian serta shalawat dan salam. Dengan hakikat wujud rasa syukur atas rahmat dan karunia yang telah dilimpahkan Allah SWT melalui RosulNya Muhammad SAW dalam membawa ajaran agama dan Al-Qur'an sebagai pedoman hidup di dunia. menyampaikan puji-pujian kepada Allah SWT, serta shalawat dan salam kepada Nabi Rasullullah Muhammad SAW. Puji-pujian serta shalawat dan salam, menjadi suatu penggambaran ungkapan serta wujud rasa syukur.

\section{KESIMPULAN DAN SARAN}

\section{Kesimpulan}

Musik Kompang sebagai kesenian Islami pada hakikatnya adalah menyampaikan puji-pujian kepada 


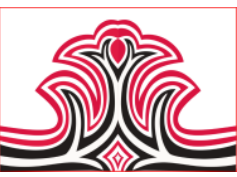

Allah SWT, serta shalawat dan salam kepada Nabi Rasullullah Muhammad SAW. Puji-pujian serta shalawat dan salam sebagai cerminan ungkapan rasa syukur kepada Allah SWT. Teknik pukulan dan sistim pertunjukan musik Kompang yang terdiri atas kesatuan permainan pola-pola gendang bermuka satu dan kosata kata vokal dengan menyenandungkan teks-teks kitab Barzanji. Keberadaan vokal sesuai dengan permainan pola-pola pukulan Kompang. Materi sajian dengan melantunkan shalawat dan salam serta puji-pujian dengan materi irama bersama "deruman" permainan Kompang. Pola-pola sajian terletak pada variasi permainan motif-motif pukulan, pola lantai hingga menggunakan persembahan pencak silat.

\section{Saran}

Sesuatu yang menarik" ialah 'kenapa kompang ada di mana-mana dalam commnunity tertentu', sebagai bagian dari tradisi mereka yang kontekstual, sedangkan pada masyarakat terutama yang bukan Melayu Riau tidak menjadikan kompang sebagai bagian dari tradisi mereka. Dalam kondisi begini, dimungkinkan untuk mengadakan penelitian lanjut bagi peneliti yang berminat untuk mendalami lebih jauh mengenai musik kompang.

Sejalan dengan konsep alam terkembang menjadi guru maka sudah sewajarnya apabila masyarakat Melayu pada umumnya seharusnya tidak hanya memfokuskan pada bidang-bidang tertentu kekeninian, namun memperluas kegiatan sosial budayanya keseluruh bidang, termasuk kesenian Islam, yang menjadi bagian dari jati dirinya. Untuk itu diperlukan regenerasi yang alamiah dan ilmiah melalui enkulturasi, baik secara formal maupun informal.

\section{DAFTAR RUJUKAN}

Armes, Hengki. (2015). Interaksi Sosial Dalam Kesenian Kompang Di Masyarakat Dusun Delik Kecamatan Bantan Kabupaten Bengkalis. Tesis tidak diterbitkan. Padangpanjang: Program Pascasarjana ISI Padangpanjang.

Brannen, Julia. (2005). Memandu Metode Penelitian Kualitatif dan Kuantitatif. Samarinda: Pustaka Pelajar.

Depdiknas. (2008). Kamus Besar Bahasa Indonesia. Jakarta: Gramedia Pustaka Utama.

Enida, Delfi. (2019). "Notasi Pukulan Kompang”. Hasil Dokumentasi Pribadi: 7 Maret 2019, Kecamatan Tualang.

Hadi, Y. Sumandiyo. (2012). Seni Pertunjukan dan Masyarakat Penonton. Yogyakarta: BP ISI Yogyakarta.
Gorga : Jurnal Seni Rupa

Volume 10 Nomor 01 Januari-Juni 2021

p-ISSN: 2301-5942 | e-ISSN: 2580-2380

Hatley, Barbara. (2014). Seni Pertunjukan Kontemporer di Jawa Tengah: Memanggungkan Identitas, Membangun Komunitas dalam Seni Pertunjukan Indonesia Pasca Orde Baru. Yogyakarta: Univ. Sanata Dharma.

Hauser, Arnold. (1982). The Sosiology of Art. Terj. Kenneth J. Northcoot. Chicago and London: The University of Chicago Press.

McHale, John. (1969). The Future of the Future. New York: George Braziller.

Nettl, Bruno. (1964). Theory and Method in Ethnomusicology. London: The Free Press of Glencoe.

Nursyirwan. (2019). "Bunyi Pukulan Kompang".

Hasil Dokumentasi Pribadi: 7 Maret 2019, Kecamatan Tualang.

Nursyirwan. (2000). Paradima Musikologis Musik Kompang Di Kelakap Tujuh Dumai Barat. Laporan penelitian tidak diterbitkan. Padangpanjang: STSI Padangpanjang.

Sari, Fani Dila, Haria Nanda Pratama, Indra Setiawan. (2020). Identifikasi Umah Adat Pitu Ruang sebagai Produk Kebudayaan Gayo. Studi Kasus: Umah Reje Baluntara Di Aceh Tengah. Gorga: Jurnal Seni Rupa, 09(2), 451-454.

Simatupang, Lono. (2013). Pergelaran sebuah Mozaik Penelitian Seni-Budaya. Yogyakarta: Jalasutra.

Steijlen, Fridus. (2014). Pasar Malam Indo-Eropa: Identitas dan Pertunjukan Kebudayaan Di Belanda”, dalam Seni Pertunjukan Indonesia Pasca Orde Baru. Yogyakarta: Univ. Sanata Dharma.

Suwardi MS. (2014). Dari Melayu ke Indonenesia. Yogyakarta: Pustaka Pelajar.

Whitehead, Alfred North. (1929). Process and Reality. New York: Free Press.

Wolf. R, Eric. (1983). Petani suatu Tinjauan Antropologis. Terjemahan TIM Yayasan IlmuIlmu Sosial. Bandung: Rajawali. 